\title{
HUBUNGAN SELF-EFFICACY DENGAN KEPATUHAN MINUM OBAT HIPERTENSI DI PUSKESMAS RANOTANA WERU KOTA MANADO
}

\author{
Kevin B. Kawulusan \\ Mario E. Katuuk \\ Yolanda B. Bataha \\ Program Studi Ilmu Keperawatan Fakultas Kedokteran \\ Universitas Sam Ratulangi \\ Email : kevinkawulusan@gmail.com
}

\begin{abstract}
Abstrack: The non-adherence towards the medication of hypertension has become one of many affections in regard to control the blood pressure. Patient's belief in medication had turned into the determinant of health behaviour and it particularly shows in what extent were the patient's adherence in dealing with the medication. The aim of this research is to know the relationship between self-efficacy and medication adherence at Public Health Center of Ranotana Weru. Research Method: The method that used in this research is cross sectional method with sample collection method using purposive sampling technique. MASES-R as measuring instrument is used to measure the self-efficacy and adherencequestionnaires to measure the medication adherence of hypertension. Sample : 85 respondents were collected as samples. Result : The statistical analysis by using Fisher's exact results $p$ values $=0,000$ with confidence level 95\% level of significance $\alpha=0,05$ means $p=0,000<p=0,05$ for self-efficacy and medication adherence of hypertension. Conclusion : There is a significant relationship between self-efficacy and medication adherence at Public Health Center of Ranotana Weru.
\end{abstract}

Keywords : Hypertension, Self-efficacy, Medication adherence.

Abstrak : Ketidakpatuhan terhadap pengobatan anti-hipertensi menjadi salah satu penyebab kurangnya pengendalian tekanan darah. Keyakinan pasien terhadap pengobatan menjadi faktor penentu perilaku kesehatan serta sejauh mana kepatuhan pasien terhadap pengobatan. Tujuan: mengetahui hubungan antara self-efficacy dengan kepatuhan minum obat hipertensi di Puskesmas Ranotana Weru Kota Manado. Metode Penelitian yang digunakan adalah cross sectional dengan teknik pengambilan sampel menggunakan purposive sampling. alat ukur yang digunakan dalah MASES-R untuk mengukur self-efficacy dan kuesioner kepatuhan untuk mengukur kepatuhan minum obat hipertensi. Sampel yang diproleh sebanyak 85 responden. Hasil Penelitian : Hasil uji statistik menggunakan uji Fisher's Exact menunjukkan nilai $p=0,000$ dengan tingkat kepercayaan 95\% derajat kemaknaan $\alpha=0,05$ yang berarti $p=0,000<p=0,05$ untuk self-efficacy dan kepatuhan minum obat hipertensi. Kesimpulan : Terdapat hubungan signifikan antara self-efficacy dengan kepatuhan minum obat hipertensi di Puskesmas Ranotana Weru Kota Manado.

Kata kunci : Hipertensi, Self-Efficacy, Kepatuhan Minum Obat. 


\section{PENDAHULUAN}

Hipertensi merupakan salah satu penyebab utama kematian mendadak di seluruh dunia dan terus berkembang setiap tahun (WHO, 2011). Jumlah penderita hipertensi di dunia terus meningkat setiap tahunnya, diperkirakan pada 2025 akan ada 1,5 miliar orang yang terkena hipertensi dan setiap tahun akan ada 9,4 juta orang meninggal akibat hipertensi dan komplikasi (WHO, 2013). Data World Health Organization (WHO) tahun 2011 menunjukkan hampir 1,8 miliar orang setiap tahun dijumpai meninggal akibat hipertensi di wilayah Asia Tenggara yang artinya kira-kira 1 dari 3 orang dewasa di Asia Tenggara memiliki tekanan darah tinggi.

Prevalensi hipertensi di Indonesia berdasarkan hasil pengukuran pada umur $\geq 18$ tahun sebesar 25,8\% (Riset Kesehatan Dasar, 2013). Data terbaru berdasarkan laporan hasil Survey Indikator Kesehatan Nasional tahun 2016 menunjukkan adanya peningkatan prevalensi hipertensi menjadi sebesar 32,38 \% yaitu $30 \%$ diantaranya di jumpai pada laki-laki dan 34,4\% pada perempuan. Di Sulawesi Utara sendiri, hipertensi termasuk dalam sepuluh penyakit menonjol dengan jumlah penderita 32.742 di tahun 2016 (Profil Kesehatan Provinsi Sulut, 2016). Berdasarkan data awal yang di peroleh dari Puskesmas Ranotana Weru Manado selama bulan Oktober - Desember 2018 terdapat 864 pasien yang terdiagnosa hipertensi.

Ketidakpatuhan terhadap pengobatan merupakan masalah kesehatan global (Jimmy \& Jose, 2011). Hasil Statistik Amerika Serikat menunjukkan sebanyak setengah dari 187 juta pasien di Amerika Serikat tidak minum obat sesuai resep yang artinya mereka tidak mengikuti intensitas rejimen obat atau tidak menggunakan obatobatan mereka selama durasi resep (American Heart Association - American Stroke Association, 2014). Sebuah studi yang dilakukan di Indonesia menunjukkan bahwa prevalensi hipertensi tanpa obat anti-hipertensi di antara 40 tahun ke atas orang dewasa populasi di Indonesia adalah $37,32 \%$ atau sama dengan 677 dari 1814 subyek hipertensi (Setiati \& Sutrisna, 2005). Ketidakpatuhan terhadap pengobatan anti-hipertensi menjadi salah satu penyebab kurangnya pengendalian tekanan darah (Tomaszewski et al., 2014). Tanpa minum obat sesuai resep, pasien tidak akan mendapat manfaat dari obat, tingkat serum obat yang adekuat tidak akan tercapai dan obat tidak akan menjadi intervensi terapeutik yang efektif. Pada akhirnya, ketidakpatuhan menyebabkan peningkatan pemanfaatan layanan kesehatan melalui perawatan masalah kronis (Latif \& McNicoll, 2009). Risiko hospitalisasi, re-hospitalisasi dan kematian dini diantara pasien hipertensi yang tidak patuh terhadap pengobatan lebih dari 5 kali lebih tinggi dibandingkan dengan pasien hipertensi yang patuh minum obat (American Heart Association - American Stroke Association, 2014).

Faktor yang mempengaruhi kepatuhan salah satu-nya ialah faktor pasien itu sendiri (patient related factor). Keyakinan pasien bahwa pengobatan akan memberikan sejumlah efek samping yang dirasa mengganggu, kekhawatiran tentang efek jangka panjang serta ketergantungan terhadap pengobatan berpengaruh terhadap kepatuhan pasien (WHO, 2003). Apa yang pasien pikirkan tentang penyakit dan pengobatannya serta keyakinan pasien terhadap pengobatan menjadi faktor penentu perilaku kesehatan serta sejauh mana kepatuhan pasien terhadap pengobatan (Mayer, 2007). Hal tersebut sejalan dengan teori kognitif sosial (sosial cognitive theory) yang dikemukakan Bandura (1989) yang menyatakan bahwa bahwa self-efficacy (keyakinan diri) berhubungan dengan perubahan perilaku seseorang (Behavioural Changes).

Self-efficacy diidentifikasi sebagai penentu meningkatnya kepatuhan yang paling menonjol dan signifikan dalam sosial cognitive theory (Holmes, 2014). Pasien yang memiliki self-efficacy tinggi 
mempunyai peluang 11 kali menunjukan kepatuhan minum obat yang baik dibandingkan pasien yang memiliki selfefficacy rendah (Novitasari, 2017). Sejalan dengan penelitian Misgiarti \& Ayu (2015) dari 143 responden disimpulkan bahwa hubungan antara tingkat keyakinan diri dan kepatuhan minum obat berbanding lurus yaitu semakin tinggi tingkat keyakinan diri maka kepatuhan minum obat akan semakin tinggi. Namun, adapun penelitian yang menyatakan tidak ada hubungan antara self-efficacy dengan kepatuhan yaitu penelitian yang dilakukakan oleh Ariesti (2018) dari 100 reponden sebagian output besar responden memiliki self-efficacy sedang, namun kepatuhan berobatnya rendah dan juga yang memiliki selfefficacy tinggi sebagian besar juga memiliki kepatuhan berobat yang rendah. Sehingga dengan demikian, masih terdapat kesenjangan hasil penelitian terkait hubungan self-efficacy dengan kepatuhan minum obat.

Berdasarkan hasil wawancara yang dilakukan pada 5 orang pasien yang melakukan kunjungan berobat di Puskesmas Ranotana Weru Manado, dijumpai 3 orang pasien mengaku tidak meminum obat anti-hipertensi saat tidak merasakan adanya keluhan atau tandatanda penyakit. Mereka juga menyatakan tidak ingin terlalu sering minum obat karena khawatir akan mengalami ketergantungan terhadap pengobatan hipertensi. Sedangkan 2 diantaranya mengaku kadang lupa minum obat karena sibuk bekerja. Dengan demikian dapat diidentifikasikan bahwa keyakinan yang di miliki penderita yang dijumpai di Puskesmas Ranotana Weru Kota Manado mengarah pada self-efficacy (keyakinan diri) yang rendah terhadap pengobatan hipertensi dimana hal tersebut akan berdampak pada perilaku kepatuhan terhadap pengobatan yang sedang penderita jalani. Diketahuinya hubungan antara self-efficacy dengan kepatuhan minum obat akan membantu perawat untuk menentukan intervensi dalam meninggkatkan self-efficacy (keyakinan diri) sebagai salah satu faktor dalam diri pasien yang dapat memberikan perubahan perilaku kepatuhan terhadap pengobatan hipertensi yang sedang pasien jalani. Berdasarkan latar belakang tersebut maka peneliti tertarik untuk melakukan penelitian tentang "Hubungan Self-Efficacy Dengan Kepatuhan Minum Obat Hipertensi di Puskesmas Ranotana Weru Kota Manado".

\section{METODE PENELITIAN}

Penelitian ini termasuk dalam jenis penelitian kuantitatif dengan menganalisis gambaran hubungan antara kedua variabel yaitu variabel independen (self-efficacy) dan variabel dependen (Kepatuhan Minum Obat Hipertensi). Penelitian ini menggunakan desain penelitian cross sectional (Sujarweni, 2014). Penelitian ini dilaksanakan di di Puskesmas Ranotana Weru Kota Manado selama Bulan September 2018 - April 2019. Populasi penelitian ini adalah seluruh pasien yang terdiagnosis hipertensi selama bulan Oktober - Desember 2018 dengan jumlah 864. Metode pengambilan sampel menggunakan Purposive Sampling sehingga didapatkan jumlah sampel sebanyak 85 penderita hipertensi. Penelitian ini dilaksanakan selama Bulan Februari 2019.

Instrumen penelitian yang digunakan untuk mengukur variabel selfefficacy menggunakan kuesioner Medication Adherence Self-Efficacy ScaleRevision (MASES-R). Kuesioner MASES$\mathrm{R}$ sudah pernah digunakan di Indonesia oleh Misgiarti \& Ayu (2015) dan telah diuji validitasnya. kuesioner ini terdiri 13 situasi berbeda, masing-masing situasi menggambarkan seberapa yakin responden mengonsumsi obat hipertensi yang diberikan, terdiri dari 4 pilihan jawaban yaitu "sama sekali tidak yakin", "sedikit yakin", "cukup yakin", "sangat yakin". Untuk pilihan jawaban "sama sekali tidak yakin" diberi skor 1, "sedikit yakin" diberi skor 2, "cukup yakin" diberi skor 3 dan 
"sangat yakin" diberi skor 4. Untuk mengukur variabel Kepatuhan Minum Obat Hipertensi menggunakan kuesioner baku kepatuhan minum obat yang diadopsi dari Sumantara (2017) yang telah di uji validitas. Kuesioner terdiri dari 10 pertanyaan dengan skala Guttman, dengan dua pilihan jawaban "ya" dan "tidak". Pilihan jawaban "ya" di beri skor 2 dan jawaban "tidak" diberi skor 1 .

Pengolahan data yang diperoleh dari hasil penelitian ini diolah secara manual dengan mengelompokkan hasil wawancara dan observasi kemudian dilakukan penghitungan skor dan dianalisis menggunakan uji statistik melalui sistem komuterisasi dengan beberapa tahap yaitu editing, coding, entering, cleaning (Notoatmodjo, 2010). Analisa bivariat dalam penelitian ini yaitu untuk mengetahui hubungan self efficacy dengan kepatuhan minum obat penderita hipertensi di Puskesmas Ranotana Weru, menggunakan uji Fisher's excact dengan tingkat kepercayaan $95 \%$ derajat kemaknaan $\alpha=0,05$.

\section{HASIL dan PEMBAHASAN}

\section{Analisa Univariat}

Tabel 1. Distribusi Responden Berdasarkan Self-Efficacy

\begin{tabular}{ccc}
\hline Self-Efficacy & $\mathbf{n}$ & $\mathbf{\%}$ \\
\hline Rendah & 19 & 22,4 \\
Tinggi & 66 & 77,6 \\
\hline Total & $\mathbf{8 5}$ & $\mathbf{1 0 0}$ \\
\hline
\end{tabular}

Sumber : Data Primer 2019

Berdasarkan tabel, tergambarkan bahwa dari 85 responden $(100 \%)$ yang di teliti di Puskesmas Ranotana Weru Kota Manado sebagian besar memiliki selfefficacy tinggi yaitu berjumlah 66 orang (77,6 \%). Penelitian ini sejalan dengan penelitian Iswari (2017), menunjukkan bahwa sebagian besar responden memiliki self-efficacy tinggi yaitu $54,7 \%$. Dalam penelitian tersebut, dijelaskan bahwa seseorang memiliki self-efficacy tinggi dipengaruhi oleh karena adanya pengalaman, seperti pengalaman rawat inap sehingga orang tersebut cenderung patuh agar penyakit yang pernah di alami tidak terulang. Menurut teori self-efficacy yang dikemukakan Bandura (1989), salah satu faktor yang mempengaruhi selfefficacy adalah faktor pengalaman terhadap keberhasilan (mastery experience) (Brown et al., 2005). Menurut Bandura (2006) individu yang memiliki self-efficacy yang tinggi menganggap kegagalan sebagai akibat dari kurangnya usaha yang keras, pengetahuan dan keterampilan. Di dalam melaksanakan berbagai tugas, orang yang mempunyai self-efficacy tinggi adalah orang yang berkinerja sangat baik dalam mengerjakan tugas tertentu, sekalipun tugas tersebut adalah tugas yang sulit, individu tersebut tidak memandang tugas sebagai suatu ancaman yang harus dihindari.

Hasil penelitian ini menunjukkan, sebagian besar responden yang memiliki self-efficacy tinggi mengaku pernah mengalami kekambuhan jika tidak minum obat teratur, sehingga mereka yakin harus minum obat sekalipun tidak memiliki gejala. Hal tersebut dapat dilihat dari jawaban yang diberikan responden dalam kuesioner Medication Adherence SelfEfficacy Scale - Revision menggambarkan bahwa, pasien yang memiliki self-efficacy tinggi yakin menjadikan minum obat sebagai suatu bagian dari rutinitas. Sekalipun sibuk, tidak diingatkan oleh keluarga atau orang terdekat, ada pengobatan lain yang bisa dijalani ataupun ketika tidak merasakan adanya tanda-tanda penyakit, mereka tetap yakin mampu mengikuti pengobatan sesuai dengan yang di rekomendasikan oleh dokter. Peneliti berasumsi bahwa, self-efficacy tinggi yang di jumpai pada responden yang di teliti Puskesmas Ranotana Weru Kota Manado muncul karena adanya pengalaman yaitu pengalaman kekambuhan terhadap penyakit hipertensi saat penderita tidak menjalankan pengobatan hipertensi sesuai dengan yang dianjurkan oleh dokter dan tenaga kesehatan. Pengalaman terhadap kekambuhan penyakit tersebut merupakan 
suatu kegagalan yang dijadikan sebagai bahan evaluasi bahwa kekambuhan yang dialami disebabkan karena perilaku tidak patuh terhadap pengobatan. Hal tersebut akan membuat penderita yakin bahwa dengan menjalani pengobatan yang sesuai, penderita akan terhindar dari resiko kekambuhan penyakit sehingga mendorong perubahan perilaku yaitu menjadi patuh dalam menjalankan pengobatan sesuai dengan yang direkomendasikan.

Tabel 2. Distribusi Responden Berdasarkan Kepatuhan Minum Obat Hipertensi

\begin{tabular}{ccc}
\hline $\begin{array}{c}\text { Kepatuhan Minum } \\
\text { Obat Hipertensi }\end{array}$ & n & \% \\
\hline Patuh & 67 & 78,8 \\
Tidak Patuh & 18 & 21,2 \\
\hline Total & $\mathbf{8 5}$ & $\mathbf{1 0 0}$ \\
\hline Sumber : Data Primer 2019 &
\end{tabular}

Berdasarkan analisis statistik menunjukkan bahwa dari 85 responden (100\%) pasien penderita hipertensi yang di teliti Puskesmas Ranotana Weru Kota Manado sebagian besar patuh minum obat hipertensi, yaitu berjumlah 67 orang $(78,8 \%)$. Sejalan dengan penelitian Damayantie dkk. (2018) menunjukkan bahwa perilaku penatalaksanaan hipertensi dipengaruhi oleh persepsi pasien terhadap penyakit yang di derita. Apa yang pasien pikirkan tentang penyakit dan pengobatannya serta keyakinan pasien terhadap pengobatan menjadi faktor penentu perilaku kesehatan serta sejauh mana kepatuhan pasien terhadap pengobatan (Mayer, 2007). Kepatuhan minum obat merupakan tingkat perilaku pasien mengikuti resep atau anjuran pengobatan sesuai dengan rekomendasi yang diberikan (Horne et al., 2005). Salah satu faktor yang mempengaruhi kepatuhan ialah faktor pasien itu sendiri (patient related factor). Keyakinan pasien bahwa pengobatan akan memberikan sejumlah efek samping yang dirasa mengganggu, kekhawatiran tentang efek jangka panjang serta ketergantungan terhadap pengobatan berpengaruh terhadap kepatuhan pasien (WHO, 2003).

Penelitian ini menunjukkan, responden yang dijumpai di Puskesmas Ranotana Weru Kota Manado memiliki persepsi yang baik terhadap penyakit dan pengobatan yang dijalani, mereka yakin bahwa dengan menjalani pengobatan sesuai dengan anjuran yang diberikan oleh dokter dan tenaga kesehatan resiko kekambuhan dan keparahan penyakit. Hal ini tergambarkan melalui jawaban responden dalam kuesioner dimana responden yang patuh minum obat selalu minum obat secara teratur, meminum obat sesuai dosis, tidak menghentikan pengobatan tanpa instruksi dokter, mengetahui jadwal minum obat, serta segera mengambil obat sesuai jadwal yang ditentukan. Peneliti berasumsi bahwa persepsi terhadap penyakit hipertensi yang dimiliki oleh penderita, turut mempengaruhi kepatuhan dimana tingkat kesadaran sebagian besar responden dalam menjalani pengobatan hipertensi di Puskesmas Ranotana Weru Kota Manado sudah sesuai dengan rekomendasi yang diberikan petugas kesehatan. Hal tersebut muncul karena pasien meyakini bahwa kepatuhan terhadap pengobatan yang dijalani akan berdampak pada penyakit yang diderita sehingga responden menunjukkan perilaku patuh terhadap pengobatan yang dijalani.

\section{Analisa Bivariat}

Tabel 3. Hubungan Self Efficacy dengan kepatuhan minum obat penderita hipertensi

\begin{tabular}{lccccccc}
\hline \multirow{2}{*}{$\begin{array}{l}\text { Self- } \\
\text { Efficacy }\end{array}$} & \multicolumn{6}{c}{ Kepatuhan Minum Obat Hipertensi } \\
\cline { 2 - 8 } & Patuh & \multicolumn{2}{c}{$\begin{array}{c}\text { Tidak } \\
\text { Patuh }\end{array}$} & Total & $\begin{array}{c}\text { P } \\
\text { Value }\end{array}$ \\
\cline { 2 - 8 } & $\mathbf{n}$ & $\%$ & $\mathbf{n}$ & $\%$ & $\mathbf{n}$ & $\%$ & \\
\hline Tinggi & 61 & 92,4 & 5 & 7,6 & 66 & 100 \\
Rendah & 6 & 31,6 & 13 & 68,4 & 19 & 100 & 0,000 \\
\hline Total & $\mathbf{6 7}$ & $\mathbf{7 8 , 8}$ & $\mathbf{1 8}$ & $\mathbf{2 1 , 2}$ & $\mathbf{8 5}$ & $\mathbf{1 0 0}$ \\
\hline
\end{tabular}

Sumber : Data Primer 2019

Berdasarkan hasil analisis statistik menggunakan uji Fisher's exact diperoleh nilai $\mathrm{p}$ value $=0,000<0,05$ sehingga $\mathrm{H}_{0}$ 
ditolak yang artinya terdapat hubungan yang signifikan antara self-efficacy dengan kepatuhan minum obat hipertensi di Puskesmas Ranotana Weru Kota Manado. Hal tersebut sesuai dengan teori Bandura (1989), bahwa self-efficacy memiliki hubungan dengan perubahan perilaku seseorang (Behavioural Changes).

Penelitian ini menunjukkan, sebagian besar responden memiliki selfefficacy tinggi dengan perilaku patuh minum obat sebanyak 61 orang $(92,4 \%)$. Sejalan dengan beberapa penelitian, seperti penelitian yang telah dilakukan Misgiarti \& Ayu (2015), menunjukkan tingkat keyakinan diri dan kepatuhan minum obat berbanding lurus yaitu semakin tinggi tingkat keyakinan diri maka kepatuhan minum obat akan semakin tinggi. Diikuti penelitian Novitasari (2017), menyimpulkan bahwa pasien yang memiliki self-efficacy yang tinggi mempunyai peluang 11 kali menunjukkan kepatuhan minum obat yang baik dibandingkan pasien yang memiliki selfefficacy rendah. Maka peneliti menyimpulkan bahwa self-efficacy atau keyakinan diri memiliki hubungan yang signifikan dengan perubahan perilaku kepatuhan seseorang dalam menjalani pengobatan hipertensi. Dalam penelitian ini, responden yang memiliki self-efficacy tinggi cenderung belajar dari pengalaman saat menjalani pengobatan hipertensi. Menurut peneliti self-efficacy yang tinggi akan mendorong seseorang untuk yakin terhadap pengobatan yang sedang dijalani. Keyakinan tersebut akan memotivasi dan meningkatkan harapan seseorang untuk mencapai kesembuhan yang akhirnya mendorong seseorang untuk berperilaku patuh dalam menjalani pengobatan hipertensi.

Berdasarkan hasil uji statistik yang diperoleh dari penelitian ini, didapati adanya kesenjangan antara hubungan selfefficacy dengan tingkat kepatuhan pengobatan penderita hipertensi di Puskesmas Ranotana Weru Kota Manado. Dimana, dalam penelitian ini dijumpai pasien hipertensi yang memiliki selfefficacy tinggi dengan perilaku tidak patuh minum obat sebanyak 5 orang $(7,6 \%)$ dan pasien hipertensi yang memiliki selfefficacy rendah dengan perilaku patuh minum obat sebanyak 6 orang $(31,4 \%)$. Menurut WHO (2003), selain faktor dari pasien itu sendiri (patient related factor) ada faktor-faktor lain yang dapat mempengaruhi kepatuhan diantaranya faktor sosial dan ekonomi (kemiskinan, pendidikan yang rendah, pengangguran, kurangnya dukungan sosial), faktor tim kesehatan/ sistem kesehatan (asuransi, kurangnya sistem distribusi obat, konsultasi yang sebentar), faktor kondisi penyakit (tingkat keparahan, tingkat kecacatan, progres penyakit), serta faktor terapi (komplektisitas regimen obat, lama pengobatan, kegagalan pengobatan sebelumnya).

Penelitian sebelumnya yang dilakukan Puspita (2017), menunjukkan bahwa ada hubungan antara tingkat pendidikan, lama menderita hipertensi, tingkat pengetahuan, serta peran petugas kesehatan dengan kepatuhan menjalani pengobatan hipertensi. Rendahya tingkat pendidikan, tingkat pengetahuan, dukungan keluarga dan peran petugas kesehatan serta menderita hipertensi selama $\geq 5$ tahun cenderung membuat pasien tidak patuh menjalani pengobatan. Hasil penelitian yang dilakukan di Puskesmas Ranotana Weru Kota Manado menunjukkan responden yang memiliki self-efficacy tinggi dengan perilaku tidak patuh telah menjalani pengobatan selama $\geq$ 5 tahun yang artinya penderita tersebut juga pasti telah menderita/terdiagnosis hipertensi selama $\geq 5$ tahun. Sebaliknya pasien hipertensi yang memiliki selfefficacy rendah dengan perilaku patuh minum obat teridentifikasi belum menjalani pengobatan selama 5 tahun. Menurut teori, semakin lama seseorang menderita hipertensi maka tingkat kepatuhannya makin rendah yang disebabkan karena kejenuhan penderita menjalani pengobatan sedangkan tingkat 
kesembuhan yang dicapai tidak sesuai dengan yang diharapkan (Gama, 2014). Selain itu, pada umumnya pasien yang telah lama menderita hipertensi tapi belum kunjung mencapai kesembuhan, biasanya akan mendapatkan tambahan jenis obat atau diberi dosis yang lebih tinggi sehingga hal tersebut akan mempengaruhi kepatuhan pasien (Puspita, 2017).

$$
\text { Menurut peneliti adanya }
$$

kesenjangan antara hubungan self-efficacy dengan tingkat kepatuhan pengobatan penderita hipertensi di Puskesmas Ranotana Weru Kota Manado diduga disebabkan karena lama pengobatan yang dijalani oleh penderita. Dimana semakin lama penderita menjalani pengobatan hipertensi yaitu $\geq 5$ tahun maka penderita akan merasa jenuh dengan pengobatan yang dijalani. Walaupun data tersebut tidak tergambarkan secara kompleks namun jika dilihat dari karakteristik responden yang peneliti jumpai di Puskesmas Ranotana Weru Kota Manado, teridentifikasi bahwa 5 orang pasien yang memiliki self-efficacy tinggi dengan perilaku tidak patuh minum obat telah menjalani pengobatan dalam rentang waktu antara 5-15 tahun. Sebaliknya 6 orang pasien hipertensi yang memiliki self-efficacy rendah dengan perilaku patuh minum obat menjalani pengobatan dalam rentang waktu $\leq 5$ tahun yaitu antara 2 bulan -4 tahun. Diduga masih ada faktor-faktor lain yang turut mempengaruhi, namun belum tergambarkan dengan jelas dalam penelitian ini sehingga dibutuhkan penelitian lebih lanjut baik dari segi faktor sosial dan ekonomi, faktor tim kesehatan/ sistem kesehatan, faktor kondisi penyakit, serta faktor terapi.

\section{SIMPULAN}

Terdapat hubungan yang signifikan antara self-efficacy dengan kepatuhan minum obat hipertensi di Puskesmas Ranotana Weru Kota Manado. Seseorang yang meniliki self-efficacy tinggi cenderung menunjukkan perilaku patuh dalam menjalani pengobatan hipertensi.
Penderita hipertensi yang dijumpai di Puskesmas Ranotana Weru Kota Manado memiliki self-efficacy tinggi. Mayoritas Penderita hipertensi di Puskesmas Ranotana Weru Kota Manado menunjukkan perilaku patuh terhadap pengobatan.

\section{DAFTAR PUSTAKA}

American Heart Association - American Stroke Association (2014). FACT SHEET: A Tough Pill to Swallow: Medication Adherence and Heart Disease. Advocacy Department, Washington, DC. www.heart.org.

Ariesti E, Pradikatama Y. (2018). Hubungan Self-Efficacy Dengan Tingkat Kepatuhan Pengobatan Hipertensi Di Puskesmas Bareng Kota Malang. Jurnal Keperawatan Malang. Vol.3. 1.39-44

Bandura, A. (1989). Social cognitive theory. In R. Vasta (Ed.), Annals of child development. Vol. 6. Six theories of child development (pp. 160). Greenwich, CT: JAI Press.

Bandura A. (2006). Chapter 14: Guide For Constructing Self-Efficacy Scale. Information Age Publishing.

Brown L.J., Malouff J.M., Schutte N.S. (2005). Self-Efficacy Theory. University of New England, Armidale.

Damayantie N., Heryani E. \& Muazir (2018). Faktor-Faktor Yang Mempengaruhi Perilaku Penatalaksanaan Hipertensi Oleh Penderita Di Wilayah Kerja Puskesmas Sekernan Ilir Kabupaten Muaro Jambi Tahun 2018. Jurnal Ners dan Kebidanan. Fakultas Keperawatan Politeknik Kesehatan Kemenkes : Jambi.

Gama I. K., Sarmadi I.W., Harini I (2014). Faktor Penyebab ketidakpatuhan 
e-journal Keperawatan(e-Kp) Volume 7 Nomor 1, Mei 2019

kontrol Penderita Hipertensi. politeknik Kesehatan Denpasar : Bali.

Holmes E.A.F., Hughes D.A., Morrison V.L. (2014). SYSTEMATIC REVIEWS : Predicting Adherence to Medications Using Health Psychology Theories: A Systematic Review of 20 Years of Empirical Research. International Society for Pharmacoeconomics and Outcomes Research (ISPOR). Elsevier Inc. http://dx.doi.org/10.1016/j.jval.2014. 08.2671 .

Horne R., Weinman J., Barber N. \& Elliott R. (2005). Concordance, Adherence And Compliance In Medication Taking. Brighton : Centre For Health Care Research.

Iswari (2017). Hubungan Self-Efficacy Dengan Kepatuhan Diit Hipertensi Di Rsud Pandan Arang Boyolali. Jurnal Stikes Kusuma Husada : Surakarta.

Jimmy B., Jose J., (2011). Patient Medication Adherence : Measure In Daily Practice. Oman Medical Journal. Vol 26. 3, 155-159. DOI 10.5001/omj.2011.38.

Latif S., McNicoll L. (2009). Medication and Non-Adherence In the Older Adult. Geriatrics For The Practicing Physician. Vol.92. 12. 418-419.

Mayer B. (2007). Non-Adherence To Treatment : A Psychological And Communication Perspective. Roger Publishing, Canadian.

Misgiarti, Ayu E. (2015). Hubungan Tingkat Keyakinan Diri Dengan Kepatuhan Minum Obat Pada Pasien Hipertensi di Poliklinik Jantung RSUD Dr. Saiful Anwar Malang. Universitas Brawijaya : Malang.
Notoadmojo. (2010). Metodologi Penelitian Kesehatan. Jakarta : PT. Rineka Cipta

Novitasari S. (2017). Skripsi : Hubungan Efikasi Diri Dengan Kepatuhan Minum Obat Pada Pasien TB Paru. Program Studi Ilmu Keperawatan Universitas Jember.

Profil Kesehatan Provinsi Sulawesi Utara 2016. (2017) . Dinas Kesehatan Daerah Provinsi Sulawesi Utara. September, 2017.

Puspita E., Oktaviarini E., Santik Y.D.P (2017). Peran Keluarga Dan Petugas Kesehatan Dalam Kepatuhan Pengobatan Penderita Hipertensi Di Puskesmas Gunungpati Kota Semarang. Jurnal Kesehatan Masyarakat Indonesia Vol.12 (2), ISSN 1693-3443. Universitas Negeri Semarang: Semarang.

Riset Kesehatan Dasar (2013). Badan Penelitian dan Pengembangan Kesehatan. Kementrian Kesehatan RI.

Setiati S., Sutrisna B. Prevalence of Hypertension without Antihypertensive Medications and Its Association with Social Demographic Characteristics Among 40 Years and Above Adult Population in Indonesia. Vol 37. 1. 20-25.

Sujarweni V.W. (2014). Metodologi Penelitian Keperawatan Yogyakarta : Gava Medika.

Sumantara I.G., Kumaat L.T., Bawotong J. (2017). Hubungan Dukungan Informative Dan Emosional Keluarga Dengan Kepatuhan Minum Obat Pada Lansia Hipertensi Di Puskesmas Ranomuut Kota Manado. Universitas Sam Ratulangi : Manado. 
e-journal Keperawatan(e-Kp) Volume 7 Nomor 1, Mei 2019

Survey Indikator Kesehatan Nasional tahun 2016. Badan Penelitian dan Pengembangan Kesehatan. Kementrian Kesehatan RI. November, 2016.

Tomaszewski M., White C., Patel P., Masca N., Damani R., Hepworth J., ... Williams B. (2014). High Rates Of Non-Adherence To Antihypertensive Treatment Revealed By HighPerformance Liquid Chromatography-Tandem Mass Spectrometry (Hp Lc-Ms/Ms) Urine Analysis. $0 . \quad 1-7$. doi:10.1136/heartjnl-2013-305063.

Vol. 11. 4. 29-32.

World Health Organization (2003). Adherence To Long-Term Therapies : Evidence For Action Report.

World Health Organization (2011). Hypertension Fact Sheet. Regional Office For Shouth-East Asia. Department of Sustainable Development and Healthy Environments.

World Health Organization (2013). A Global Brief On Hypertension. Executive Summary.

World Health Organization (2013). High Blood Pressure Global And Regional Overview. World Health Day 2013. 